\title{
Cerebellar Ataxia with
} Complete Clinical Recovery and Resolution of MRI Lesions Related to Central Pontine Myelinolysis: Case Report and Literature Review

\author{
Cristina Dolciotti $^{\mathrm{b}} \quad$ Angelo Nuti $^{\mathrm{a}}$ Gabriele Cipriani $^{\mathrm{a}}$ \\ Paolo Borellia Filippo Baldacci ${ }^{b}$ Chiara Logia \\ Ubaldo Bonuccellib
}

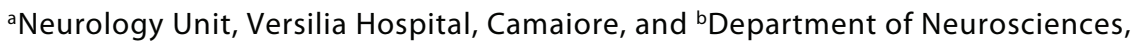
University of Pisa, Pisa, Italy

\section{Key Words}

Central pontine myelinolysis - Cerebellar ataxia - Chemotherapy · Complete recovery . Hyponatremia

\begin{abstract}
There are several reports of central pontine myelinolysis (CPM) in a setting of malnutrition, alcoholism, and chronic debilitating illness associated with electrolyte abnormalities, especially hyponatremia. The cause of myelinolysis is still under debate, and, although osmotic effects are thought to be responsible in most cases, alternative pathological factors should be considered [King et al.: Am J Med Sci 2010;339:561-567]. We report a case of CPM in a patient with recent chemotherapy for colon cancer without electrolyte unbalance and otherwise unexplained causes. Moreover, the present case is an example of the unusual clinical ataxic variant, followed by complete recovery without any specific treatment. The diagnosis was confirmed by MRI, which showed a characteristic hyperintense signal abnormality in the central part of the pons with an unaffected outer rim. One month later, we observed complete resolution of clinical and radiological symptoms.
\end{abstract}




\begin{tabular}{l|l|l|l} 
Case Reports in & $\begin{array}{l}\text { Case Rep Neurol 2010;2:157-162 } \\
\text { DOl: 10.1159/000323429 }\end{array}$ & $\begin{array}{l}\text { Published online: } \\
\text { December 22, 2010 }\end{array}$ & $\begin{array}{l}\text { ISSN 1662-680X } \\
\text { www.karger.com/crn }\end{array}$ \\
\hline
\end{tabular}

\section{Introduction}

Central pontine myelinolysis (CPM) was first described in 1959 by Adams [2] in patients with a history of alcohol abuse. It has been classically defined as a symmetrical and selective destruction of myelin sheaths in the central portion of the basis pontis, without evidence of an underlying vascular lesion or signs of inflammation detectable on MRI.

In the clinical setting, CPM has been reported mainly in association with rapid correction of hyponatremia, but also in other medical conditions, such as hypernatremia, hypokalemia, the syndrome of inappropriate antidiuretic hormone hypersecretion (SIADH), liver and renal transplantation, severe liver disease, chronic alcoholism, malnutrition, anorexia nervosa and hyperemesis gravidarum. It has also been reported in association with Wernike's encephalopathy, Wilson's disease, brain tumors, brain edema, adrenal insufficiency, carcinoma and Hodgkin's disease, chemotherapy, HIV infection, immunosuppression and autoimmune mechanisms. It has frequently been reported autoptically in asymptomatic patients $[3,4]$.

Clinical features include mental status changes, quadriparesis, pseudobulbar palsy, whereas cerebellar ataxia is an extremely unusual sign in CPM. We report a case of ataxia in CPM with a complete clinical and radiological recovery.

\section{Case Report}

A right-handed 74-year-old man was admitted to our hospital in May 2007 for gait disturbances for 2 days. There was no prior history of any neurological disorder. The patient underwent partial colectomy for a sigma colon cancer with lung metastasis, and he received chemotherapy with 5-fluorouracil and oxaliplatin. Neurological examination showed a significant truncal and limb ataxia with bilateral intention tremor. Cranial nerve function was normal, nystagmus was absent, power and sensory function in all 4 limbs as well as deep tendon reflexes were normal, and plantar responses were flexor bilaterally. Brain MRI with gadolinium showed some central pontine lesions without significant mass effect or contrast enhancement consistent with CPM. There were no other abnormalities in the rest of the brain ( $\underline{\text { fig. } 1}$ ). Several blood tests showed mild neutropenia, low serum levels of total cholesterol and albumin, but no evidence of electrolyte abnormalities (sodium: $138 \mathrm{mEq} / \mathrm{l}$, potassium: $3.7 \mathrm{mEq} / \mathrm{l}$, calcium: $9.3 \mathrm{mg} / \mathrm{dl}$, phosphorus: $4.50 \mathrm{mg} / \mathrm{dl}$, bicarbonate: $35 \mathrm{mEq} / \mathrm{l}$, magnesium: $1.9 \mathrm{mg} / \mathrm{dl}$ ). The patient gradually improved without any specific treatment, and after 1 month, the neurological picture was back to normal. Moreover, a second brain MRI with gadolinium carried out 2 months later was unremarkable (fig. 2).

\section{Discussion}

$\mathrm{CPM}$ is an uncommon demyelinating disorder of unknown etiology. The mechanism of CPM is not well understood. Although in the original description of CPM by Adams there was no mention of electrolyte unbalance, it has become clear that osmotic balance is correlated to CPM in most cases. The factors implicated in CPM include alcohol abuse, malnutrition, diseases (such as chronic debilitation, cerebral ischemia, impaired fat metabolism, and infections), individual predisposition, dehydration, osmolarity fluctuations, liver dysfunction, SIADH, and prolonged diuretic use.

Histologic studies have shown that oligodendrocytes are susceptible to CPM-related osmotic stress, especially making high-density brain areas, such as the central pons, 
thalamus, cortex, putamen, lateral geniculate, and other extrapontine sites, vulnerable to this mechanism [1]. The neurons and axons are typically preserved, unlike in central pontine infections. There is no inflammatory reaction associated with osmotic demyelination, differentiating this process from multiple sclerosis, which is characterized by marked perivascular inflammation. In several reports, CPM is well described as a complication of chronic hyponatremia correction, especially when the correction occurs rapidly. Therefore, CPM is also known as osmotic demyelination syndrome, caused by release of toxic compounds [1-4].

In a recent case report, severe CPM accompanied by unusual extensive extrapontine myelinolysis was described in a chronic alcohol abuser without hyponatremia. The patient underwent methylprednisolone pulse therapy. After 7 weeks' serial follow-up, MRI revealed a complete resolution of extrapontine myelinolysis, but the pons lesions remained unchanged [5]. In the present case, there was no evidence of electrolyte abnormalities. Furthermore, the clinical setting gradually improved without any treatment, and after 1 month the neurological picture was back to normal.

Although we cannot rule out that our patient had suffered from minor fluctuations in serum sodium levels between the measurements, our patient presented with no evidence of hyponatremia based on the available data. On the other hand, the MRI abnormality is unlikely to be vascular in nature given the normal diffusion-weighted imaging sequences.

Our case of CPM occurred in a patient with colon cancer metastasized to the lungs. Previously, another case of lung carcinoma and CPM was reported, but associated with SIADH [6]. CPM was also observed in 2 cases of nasopharyngeal carcinoma after cisplatin chemotherapy. This treatment is increasingly used in advanced head and neck cancers, and hyponatremia - usually regarded as a mild entity - is a common therapy complication [11]. Our patient did not develop hyponatremia after chemotherapy. Moreover, in our case, cerebellar symptoms were the main clinical findings. Cerebellar ataxia as the prevalent clinical sign of CPM is extremely rare, and it was only described in isolated reports (table 1) [7-14].

As in our patient, in all other cases of CPM with cerebellar ataxia, brain MRI with gadolinium revealed the presence of central pontine lesions, whereas a frontal atrophy and a moderate cerebellar atrophy were observed only in 1 case [13]. This neurological disorder is increasingly recognized, especially due to MRI, which shows the typical findings in the central pons: hypointense lesions in sagittal T1-weighted images and a triangular area hyperintense on axial T2-weighted images.

In conclusion, in the literature, only 1 case of CPM with cerebellar ataxia in association with malignancy is reported; however, unlike our case, this patient presented with SIADH and underwent correction of hyponatremia after chemotherapy [14]. The cause of myelinolysis remains under debate, and although osmotic effects seem to be responsible in most patients, the role of malignancy should be considered because it may be more common than the literature suggest. 


\begin{tabular}{c|l|l|l} 
Case Reports in & $\begin{array}{l}\text { Case Rep Neurol 2010;2:157-162 } \\
\text { DOI: } 10.1159 / 000323429\end{array}$ & $\begin{array}{l}\text { Published online: } \\
\text { December 22, 2010 }\end{array}$ & $\begin{array}{l}\text { ○ 2010 S. Karger AG, Basel } \\
\text { ISSN 1662-680X } \\
\text { www.karger.com/crn }\end{array}$ \\
\hline
\end{tabular}

Table 1. Cases of CPM with ataxia

\begin{tabular}{|c|c|c|c|c|c|c|c|c|c|c|}
\hline Reference & Case & $\begin{array}{l}\text { Clinical } \\
\text { picture }\end{array}$ & $\begin{array}{l}\text { Alcoholism/ } \\
\text { malnutrition }\end{array}$ & $\begin{array}{l}\text { Electrolyte } \\
\text { disturbance }\end{array}$ & $\begin{array}{l}\text { Can- } \\
\text { cers }\end{array}$ & $\begin{array}{l}\text { Paraneo- } \\
\text { plastic } \\
\text { syndromes }\end{array}$ & Treatment & $\begin{array}{l}\text { Chemo- } \\
\text { therapy }\end{array}$ & Outcome & $\begin{array}{l}\text { MRI } \\
\text { follow-up }\end{array}$ \\
\hline $\begin{array}{l}\text { Defebre } \\
\text { et al., } \\
1995 \text { [7] }\end{array}$ & 2 & $\begin{array}{l}\text { ataxia, } \\
\text { intention } \\
\text { tremor, } \\
\text { dysarthria }\end{array}$ & yes/no & $\begin{array}{l}\text { hyponatremia, } \\
\text { hypokalemia }\end{array}$ & no & no & $\begin{array}{l}\text { hyponatremia } \\
\text { correction }\end{array}$ & no & $\begin{array}{l}\text { neurological } \\
\text { sequelae }\end{array}$ & $\begin{array}{l}\text { CPM } \\
\text { EPM }^{1}\end{array}$ \\
\hline $\begin{array}{l}\text { Gille } \\
\text { et al., } \\
1993 \text { [8] }\end{array}$ & 1 & $\begin{array}{l}\text { ataxia, } \\
\text { intention } \\
\text { tremor, } \\
\text { hypotonia, } \\
\text { dysarthria }\end{array}$ & yes/no & $\begin{array}{l}\text { hyponatremia, } \\
\text { hypokalemia }\end{array}$ & no & no & $\begin{array}{l}\text { hyponatremia } \\
\text { correction }\end{array}$ & no & $\begin{array}{l}\text { alcoholic } \\
\text { dementia }\end{array}$ & $\begin{array}{l}\mathrm{CPM} \\
\mathrm{EPM}^{2}\end{array}$ \\
\hline $\begin{array}{l}\text { Steller } \\
\text { et al., } \\
1988 \text { [9] }\end{array}$ & 1 & $\begin{array}{l}\text { ataxia, } \\
\text { intention } \\
\text { tremor, } \\
\text { hypotonia, } \\
\text { dysarthria }\end{array}$ & yes/no & $\begin{array}{l}\text { hyponatremia, } \\
\text { hypokalemia }\end{array}$ & no & no & $\begin{array}{l}\text { hyponatremia } \\
\text { correction }\end{array}$ & no & $\begin{array}{l}\text { no } \\
\text { neurological } \\
\text { sequelae }\end{array}$ & $\begin{array}{l}\text { CPM } \\
\text { EPM }^{1}\end{array}$ \\
\hline $\begin{array}{l}\text { Rajbhandari } \\
\text { et al., } \\
1998 \text { [10] }\end{array}$ & 1 & $\begin{array}{l}\text { ataxia, } \\
\text { intention } \\
\text { tremor, } \\
\text { hypotonia, } \\
\text { dysarthria }\end{array}$ & yes/no & $\begin{array}{l}\text { hyponatremia, } \\
\text { hypokalemia }\end{array}$ & no & no & $\begin{array}{l}\text { hyponatremia } \\
\text { correction }\end{array}$ & no & $\begin{array}{l}\text { no } \\
\text { neurological } \\
\text { sequelae }\end{array}$ & $\begin{array}{l}\text { CPM } \\
\text { EPM }^{1}\end{array}$ \\
\hline $\begin{array}{l}\text { Menger } \\
\text { and Jörg, } \\
1999 \text { [11] }\end{array}$ & 2 & ataxia & yes/no & Hyponatremia & no & no & $\begin{array}{l}\text { hyponatremia } \\
\text { correction, } \\
\text { methyl- } \\
\text { prednisolone }\end{array}$ & no & $\begin{array}{l}\text { severe ataxia } \\
\text { for } 4-7 \\
\text { months }\end{array}$ & $\mathrm{CPM}$ \\
\hline $\begin{array}{l}\text { Hagiwara } \\
\text { et al., } \\
2008 \text { [12] }\end{array}$ & 1 & $\begin{array}{l}\text { ataxia, } \\
\text { pyramidal } \\
\text { spasticity, } \\
\text { extrapy- } \\
\text { ramidal } \\
\text { rigidity }\end{array}$ & yes/no & $\begin{array}{l}\text { no electrolyte } \\
\text { abnormalities }\end{array}$ & no & no & $\begin{array}{l}\text { methyl- } \\
\text { prednisolone }\end{array}$ & no & $\begin{array}{l}\text { no } \\
\text { neurological } \\
\text { sequelae }\end{array}$ & $\begin{array}{l}\mathrm{CPM} \\
\text { (resolu- } \\
\text { tion } \\
\text { EPM) }\end{array}$ \\
\hline $\begin{array}{l}\text { Garzon et al., } \\
2002 \text { [13] }\end{array}$ & 1 & ataxia & yes/no & $\begin{array}{l}\text { no electrolyte } \\
\text { abnormalities }\end{array}$ & no & no & no & no & $\begin{array}{l}\text { no } \\
\text { neurological } \\
\text { sequelae }\end{array}$ & $\mathrm{CPM}$ \\
\hline $\begin{array}{l}\text { Yau } \\
\text { et al., } \\
1993 \text { [14] }\end{array}$ & 1 & $\begin{array}{l}\text { ataxia, } \\
\text { dysphagia, } \\
\text { dysarthria }\end{array}$ & no/no & hyponatremia & yes $^{3}$ & SIADH & $\begin{array}{l}\text { hyponatremia } \\
\text { correction }\end{array}$ & $\begin{array}{l}\text { cis- } \\
\text { platine }\end{array}$ & $\begin{array}{l}\text { no } \\
\text { neurological } \\
\text { sequelae }\end{array}$ & CPM \\
\hline $\begin{array}{l}\text { Present case } \\
\text { report }\end{array}$ & 1 & $\begin{array}{l}\text { ataxia, } \\
\text { intention } \\
\text { tremor }\end{array}$ & no/no & $\begin{array}{l}\text { no electrolyte } \\
\text { abnormalities }\end{array}$ & yes $^{4}$ & no & no & $\begin{array}{l}\text { 5-fluoro- } \\
\text { uracil, } \\
\text { oxali- } \\
\text { platin }\end{array}$ & $\begin{array}{l}\text { no } \\
\text { neurological } \\
\text { sequelae }\end{array}$ & $\begin{array}{l}\text { recov- } \\
\text { ery }\end{array}$ \\
\hline
\end{tabular}

${ }^{1}$ Cerebellar peduncles. ${ }^{2}$ Cerebellar peduncles; mild cerebellar atrophy. ${ }^{3}$ Nasopharyngeal carcinoma. ${ }^{4}$ Sigma-colon cancer. EPM = Extrapontine myelinolysis. 


\begin{tabular}{|c|c|c|c|}
\hline $\begin{array}{l}\text { Case Reports in } \\
\text { Nellooys }\end{array}$ & \begin{tabular}{|l} 
Case Rep Neurol 2010;2:157-162 \\
DOI: 10.1159/000323429
\end{tabular} & $\begin{array}{l}\text { Published online: } \\
\text { December 22, } 2010\end{array}$ & $\begin{array}{l}\text { ( ) } 2010 \text { S. Karger AG, Basel } \\
\text { ISSN } 1662-680 X \\
\text { www.karger.com/crn }\end{array}$ \\
\hline
\end{tabular}

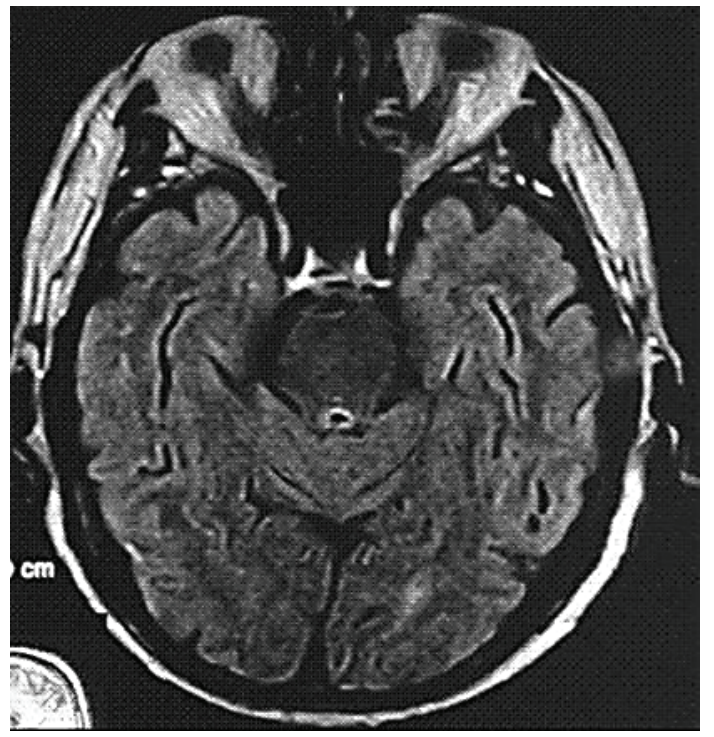

Fig. 1. Brain MRI with gadolinium proved the presence of central pontine lesions without significant mass effect.

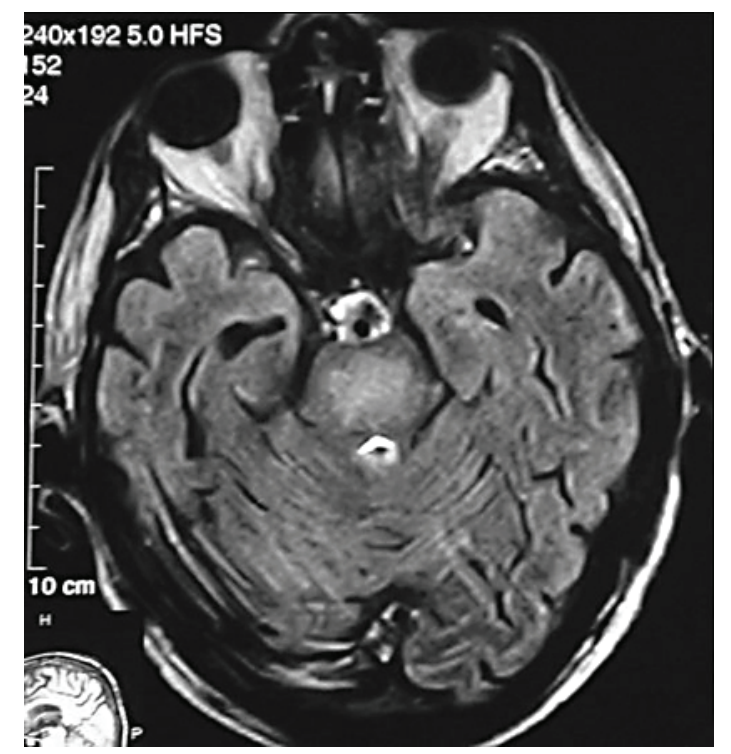

Fig. 2. The brain MRI in T2 flair showed the resolution of the central pontine lesions. 


\begin{tabular}{l|l|l|l} 
Case Reports in & $\begin{array}{l}\text { Case Rep Neurol 2010;2:157-162 } \\
\text { DOI: 10.1159/000323429 }\end{array}$ & $\begin{array}{l}\text { Published online: } \\
\text { December 22, 2010 }\end{array}$ & $\begin{array}{l}\text { ISSN 1662-680X } \\
\text { ISWw. Karger AG, Basel } \\
\text { www.karger.com/crn }\end{array}$ \\
\hline
\end{tabular}

\section{References}

1 King JD, Rosner MH: Osmotic demyelination syndrome. Am J Med Sci 2010;339:561-567.

-2 Adams RA, Victor M, Mancall EL: Central pontine myelinolysis: a hitherto undescribed disease occurring in alcoholics and malnourished patients. Arch Neurol Psychiatry 1959;81:154-172.

-3 Yuh WT, Simonson TM, D’Alessandro MP, et al: Temporal changes of MR findings in central pontine myelinolysis. Am J Neuroradiol 1995;16:975-977.

-4 Huq S, Wong M, Chan $\mathrm{H}$, et al: Osmotic demyelination syndromes: central and extrapontine myelinolysis. J Clin Neurosci 2007;14:684-688.

5 Menger H, Jörg J: Outcome of central pontine and extrapontine myelinolysis. Neurol 1999;246:700-705.

6 Hardjasudarma M, Husain F, Fowler M, et al: Central pontine myelinolysis as a manifestation of the paraneoplastic syndrome. South Med J 1992;85:419-421.

7 Defebre L, Rogelet P, Deste A, et al: Regressive dystonia and cerebellar ataxia: two unusual symptoms in central pontine myelinolysis. Journal Neurology 1995;242:450-454.

-8 Gille M, Jacquemin C, Kiame G, et al: Central pontine myelinolysis with cerebellar ataxia and dystonia. Rev Neurol 1993;149:344-346.

-9 Steller U, Koschorek F, Strenge H: Cerebellar ataxia with recovery related to central pontine myelinolysis. J Neurol 1988;235:379-381

10 Rajbhandari SM, Powell T, Davies-Jones GA, Ward JD: Central pontine myelinolysis and ataxia: an unusual manifestation of hypoglycaemia. Diabet Med 1998;15:259-261.

11 Menger H, Jörg J: Outcome of central pontine and extrapontine myelinolysis. Neurol 1999;246:700-705.

12 Hagiwara K, Okada Y, Shida N, et al: Extensive central and extrapontine myelinolysis in a case of chronic alcoholism without hyponatremia: a case report with analysis of serial MR findings. Intern Med 2008;47:431435 .

13 Garzon T, Mellibovsky L, Roquer J, et al: Ataxic form of central pontine myelinolysis. Lancet Neurol 2002;1:517-518

14 Yau TK, Yiu HY, Lee WM: Central pontine myelinolysis: report of two occurrences after cisplatin-containing chemotherapy for nasopharyngeal carcinoma. Clin Oncol 1993;5:395-396. 